\title{
THE MICROSTRUCTURE AND TEXTURE OF WARM ROLLED 3004 ALUMINIUM
}

\author{
G. O. SCHUMANN*, A. CROSKY and M. HATHERLY \\ School of Materials Science and Engineering, University of New South Wales, \\ Sydney 2052 Australia \\ *now at CSIRO, Division of Manufacturing Technology, \\ PO Box 4 Woodville 5011 Australia \\ Dedicated to the memory of Professor Dr. Dr.(h.c.) Hsun Hu (Bill)
}

(Received 6 November 1995)

\begin{abstract}
The effect of warm/hot rolling temperature on the microstructure and texture of a commercial grade 3004 alloy has been examined for material solution treated at two different temperatures $\left(580^{\circ}\right.$ and $400^{\circ} \mathrm{C}$ ). The first of these would be expected to maximise the solute concentration and particle spacing while the second should result in a dispersion of fine particles. Microstructural heterogeneity was not observed in material rolled to $75 \%$ reduction in a single pass at temperatures $>400^{\circ} \mathrm{C}$. This is reflected in the textures where the ODF's are flat and the $\beta$ fibre weak and uniform. In material rolled after being re-heated to $200^{\circ} \mathrm{C}$ and $300^{\circ} \mathrm{C}$ heterogeneity and banded microstructures were observed. This was less marked for specimens solution treated at $400^{\circ} \mathrm{C}$. Shear bands formed only in material solution treated at $580^{\circ} \mathrm{C}$. A strong $\mathrm{C}$ component was found only in the texture of specimens solution treated at $400^{\circ} \mathrm{C}$ and rolled at $200^{\circ} \mathrm{C}$ and $300^{\circ} \mathrm{C}$. These effects are believed to have their origin in differences in the extent of dynamic recovery.
\end{abstract}

KEY WORDS: Microstructure, heterogeneity, banded structures, texture, ODF, dynamic recovery.

\section{INTRODUCTION}

Very large quantities of the alloy 3004 are used in the manufacture of aluminium beverage cans and much attention has been paid to the control of earing in the deep drawing stages of manufacture. The textures present in the rolled can stock have been extensively investigated and it is well known that the best results are associated with a balanced texture which leads to 4-fold earing at $0 / 90^{\circ}$ together with earing at $\pm 45^{\circ}$ (Hutchinson et al, 1989). The first of these is derived from the presence of a cube texture component that is generated at the end of the hot rolling and annealing stages and partly retained during cold rolling. The second is the result of the cold rolling operation of $\sim 90 \%$ reduction in which the normal fcc rolling texture components, $\mathrm{C}$ $=\{112\}<111>, B=\{110\}<112>$ and $S$ (or $R)=\{123\}<634>$ ) are developed.

The balancing of these components in a complex, multi-phase alloy like 3004 is not easy. The final texture is affected not only by the annealing and cold rolling operations mentioned above but also by the microstructure and texture of the cast ingot, the changes occurring during homogenisation and the temperature of hot rolling. The nucleation of the required cube texture grains depends on the presence of particular microstructural inhomogeneities of deformation in the matrix and the development of these requires that a degree of cold working be present during the so called "hot rolling" stage. A 
second factor is related to the second phase particles present in the microstructure during hot rolling. If these are larger than $\sim 2 \mu \mathrm{m}$, particle stimulated nucleation (PSN) will ensure that the desired cube texture is replaced by a more random texture. To overcome this problem, the temperature during hot rolling must be high enough to prevent PSN at the larger particles.

In this paper we are concerned with commercial quality 3004 which has been heated to two different temperatures $\left(400^{\circ} \mathrm{C}\right.$ and $\left.580^{\circ} \mathrm{C}\right)$ and then hot rolled at temperatures in the range $200-400^{\circ} \mathrm{C}$ or $200-580^{\circ} \mathrm{C}$ respectively. It was expected that these treatments would either reduce or maximise the solute content of the matrix material and provide information about the effects of rolling temperature on the textures developed.

\section{EXPERIMENTAL}

Samples $140 \mathrm{~mm}$ long, $38 \mathrm{~mm}$ wide and $12 \mathrm{~mm}$ thick were cut from a slab of commercial grade 3004 alloy. A tapered lead-in section, $100 \mathrm{~mm}$ long was provided to facilitate the subsequent heavy rolling pass. The composition of the material is given below:

$$
\begin{array}{cccccccc}
\mathrm{Si} & \mathrm{Fe} & \mathrm{Cu} & \mathrm{Mn} & \mathrm{Mg} & \mathrm{Cr} & \mathrm{Zn} & \mathrm{Ti} \\
0.30 & 0.36 & 0.22 & 0.96 & 1.23 & 0.01 & <0.01 & <0.01 \text { (wt.\%) }
\end{array}
$$

Six different heat treatments were used. In three of these, samples were heated for 3 hours at $400^{\circ} \mathrm{C}$, and in the remainder, the samples were heated for 48 hours at $580^{\circ} \mathrm{C}$. One sample from each group was rolled immediately at the temperature used and then quenched. The remaining samples from each group were quenched and then reheated for 1 hour at either $200^{\circ} \mathrm{C}$ or $300^{\circ} \mathrm{C}$ before rolling at that temperature. The samples were rolled in a two high mill with $200 \mathrm{~mm}$ rolls at $0.85 \mathrm{~m} / \mathrm{sec}$ to $75 \%$ reduction in a single pass. The microstructure was examined in a TEM using thin foil specimens perpendicular to the transverse direction and texture examination was made on midplane sections. Four incomplete pole figures $(111,200,220$, and 311$)$ were used to calculate the orientation distribution function (ODF), in the form of series expansion coefficients to order 22. The ODF's shown below have been corrected for ghost errors.

\section{RESULTS}

\section{Particle size and distribution}

The starting material contained coarse, angular particles of a primary A1MnFeSi type phase distributed in an aligned, banded structure. The particles were up to $12 \mu \mathrm{m}$ long and $4 \mu \mathrm{m}$ wide. A more uniformly distributed population of finer secondary particles of A1MnSi type was also present. Details of the spacing of these particles after the various heating and rolling programmes are given in Table 1.

In samples examined after solution treatment at $400^{\circ} \mathrm{C}$ the secondary particles were rod shaped with typical length and diameter of $400 \mathrm{~nm}$ and $100 \mathrm{~nm}$ respectively (figure 1). In all figures the scale marker is parallel to the rolling direction. The mean particle spacing was $\sim 250 \mathrm{~nm}$. No significant changes in size, shape or distribution of these particles occurred after rolling directly at $400^{\circ} \mathrm{C}$ or after re-heating to, and rolling at, $200^{\circ} \mathrm{C}$ and $300^{\circ} \mathrm{C}$. The particles present in material solution treated and rolled at $580^{\circ} \mathrm{C}$ were more equiaxed with diameter $\sim 400 \mathrm{~nm}$, and more widely dispersed with 
mean spacing $\sim 380 \mathrm{~nm}$ (figure 2). Once again heating to $200^{\circ} \mathrm{C}$ and $300^{\circ} \mathrm{C}$, followed by rolling at that temperature, produced no significant changes in size, shape or distribution of the particles.

Table 1 Metallographic Data.

\begin{tabular}{lccccc}
\hline $\begin{array}{l}\text { Solution } \\
\text { Treatment, }{ }^{\circ} \mathrm{C}\end{array}$ & Ageing, ${ }^{\circ} \mathrm{C}$ & Rolling, ${ }^{\circ} \mathrm{C}$ & $\begin{array}{c}\text { Particle } \\
\text { Spacing, } n m\end{array}$ & $\begin{array}{c}\text { Subgrain } \\
\text { Length, } n m\end{array}$ & $\begin{array}{c}\text { Subgrain } \\
\text { Thickness, nm }\end{array}$ \\
\hline 400 & nil & nil & 250 & 4600 & \\
400 & nil & 400 & 260 & 1050 & 660 \\
400 & 300 & 300 & 250 & 560 & 400 \\
400 & 200 & 200 & 210 & 620 & 390 \\
580 & nil & nil & & no subgrains & 730 \\
580 & nil & 580 & 370 & 1380 & 260 \\
580 & 300 & 300 & 390 & 710 & 340 \\
580 & 200 & 200 & 340 & 820 & \\
\hline
\end{tabular}

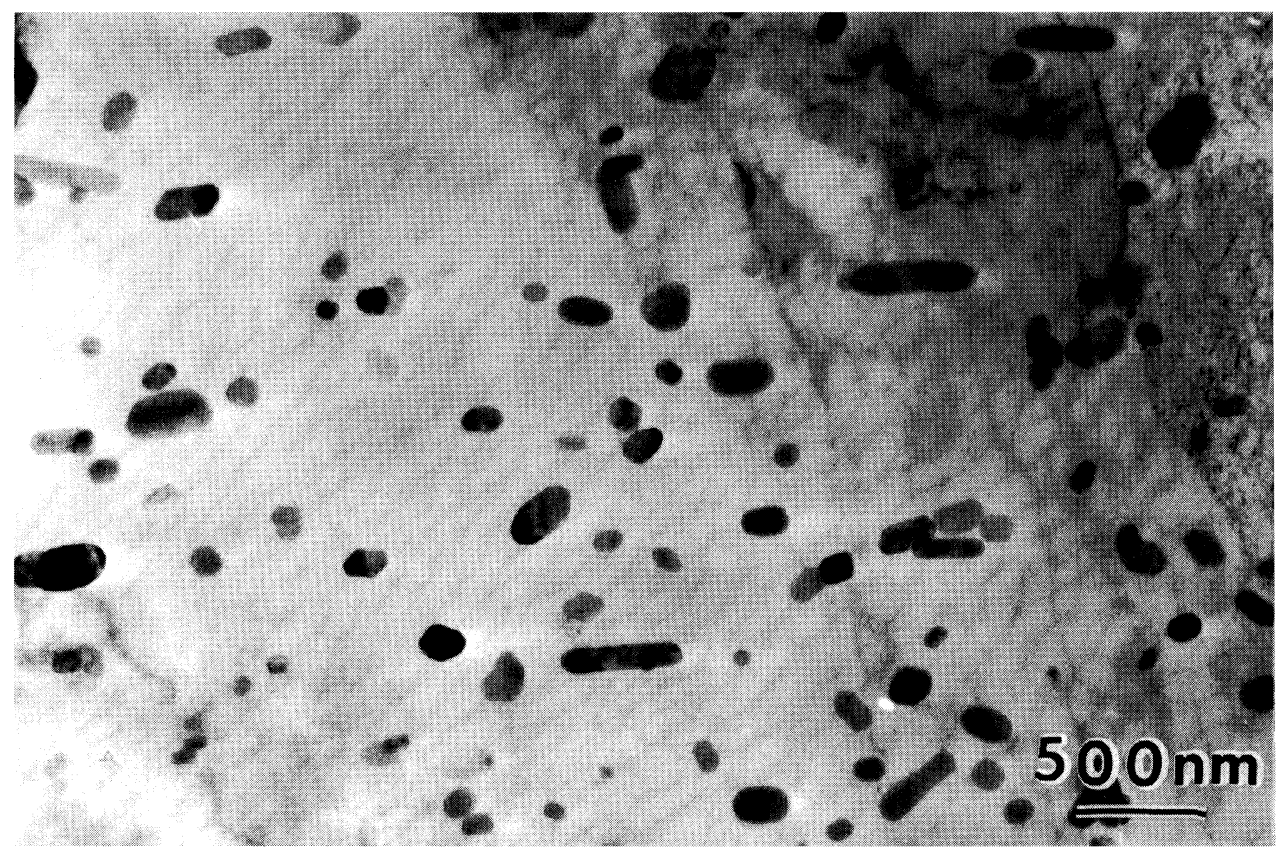

Figure $1 \mathrm{~A} 1 \mathrm{MnSi}$ particles after solution treatment for 3 hours at $400^{\circ} \mathrm{C}$. 


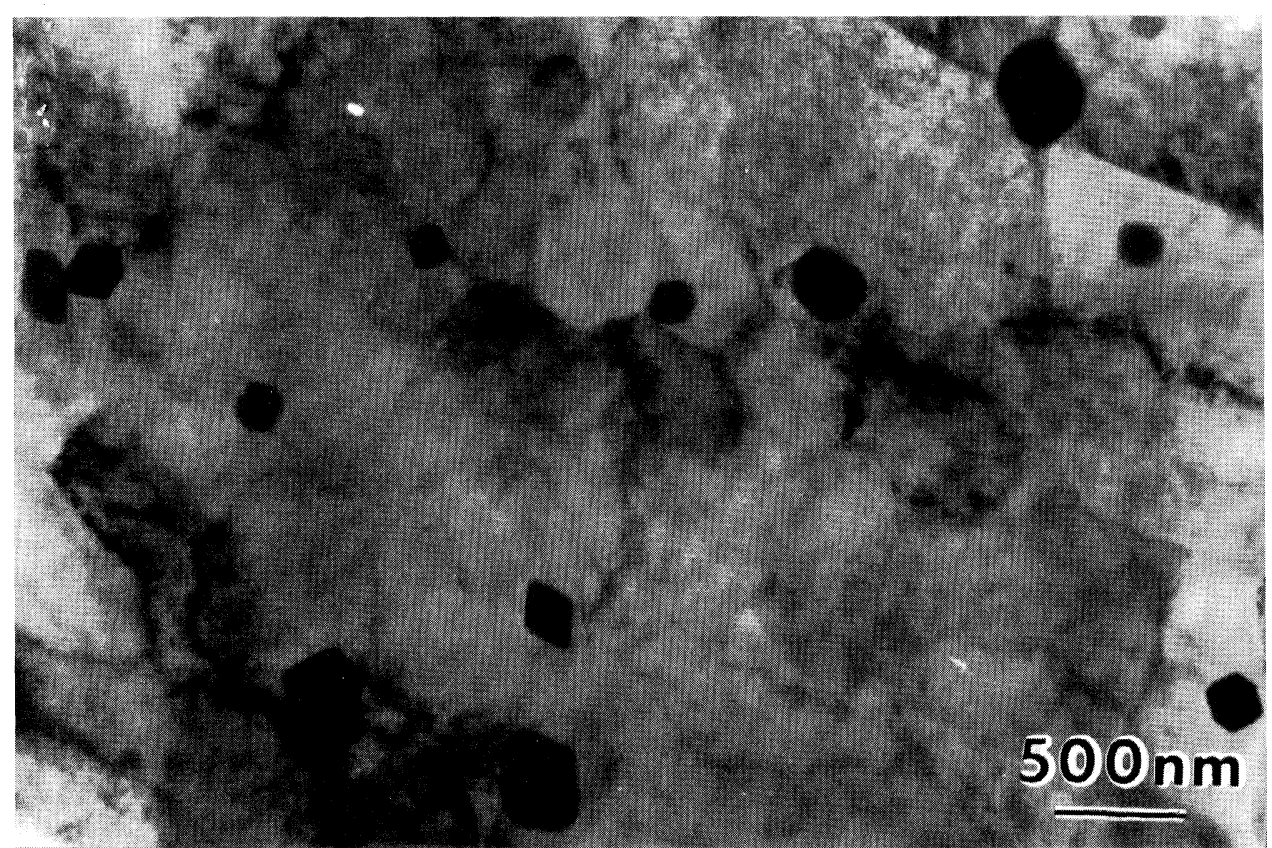

Figure $2 \mathrm{~A} 1 \mathrm{MnSi}$ particles after solution treatment for 48 hours at $580^{\circ} \mathrm{C}$.

\section{Microstructure}

The substructure of specimens solution treated at $400^{\circ} \mathrm{C}$ consisted of well developed subgrains with clearly defined boundaries and relatively low dislocation densities (figure 3). In general the subgrains were equiaxed with a mean diameter $4600 \mathrm{~nm}$ (Table 1) but occasional elongated subgrains were observed. Rolling immediately after treatment at $400^{\circ} \mathrm{C}$ led to a reduction in size of the subgrains, which were then mostly elongated with mean length $1050 \mathrm{~nm}$ and thickness $\sim 650 \mathrm{~nm}$. The boundaries of the subgrains were sharp and the internal dislocation content was relatively high (figure 4). The local misorientation at the boundary was low and only rarely exceeded $5^{\circ}$.

After rolling at $200^{\circ} \mathrm{C}$ and $300^{\circ} \mathrm{C}$ the structure consisted of a matrix of smaller, slightly elongated subgrains with an occasional, superimposed band structure (figure 5). The matrix subgrains were $\sim 600 \mathrm{~nm}$ long and $400 \mathrm{~nm}$ thick (see Table 1). The banded structure consisted of clusters of up to 10 elongated features that were often many microns long and 200-500 $\mathrm{nm}$ thick; the clustered bands were inclined to the rolling plane at angles up to $25^{\circ}$. The boundaries in both the structural units were sharp and the orientations of both were within $\sim 5^{\circ}$ of each other; the internal dislocation contents were similar to that of material rolled at $400^{\circ} \mathrm{C}$. At the lower rolling temperature $\left(200^{\circ} \mathrm{C}\right)$ the banded structure was more frequent and the bands were narrower ( 200-350 nm). Major microstructural inhomogeneities, such as shear bands, were not observed in specimens solution treated at $400^{\circ} \mathrm{C}$. 


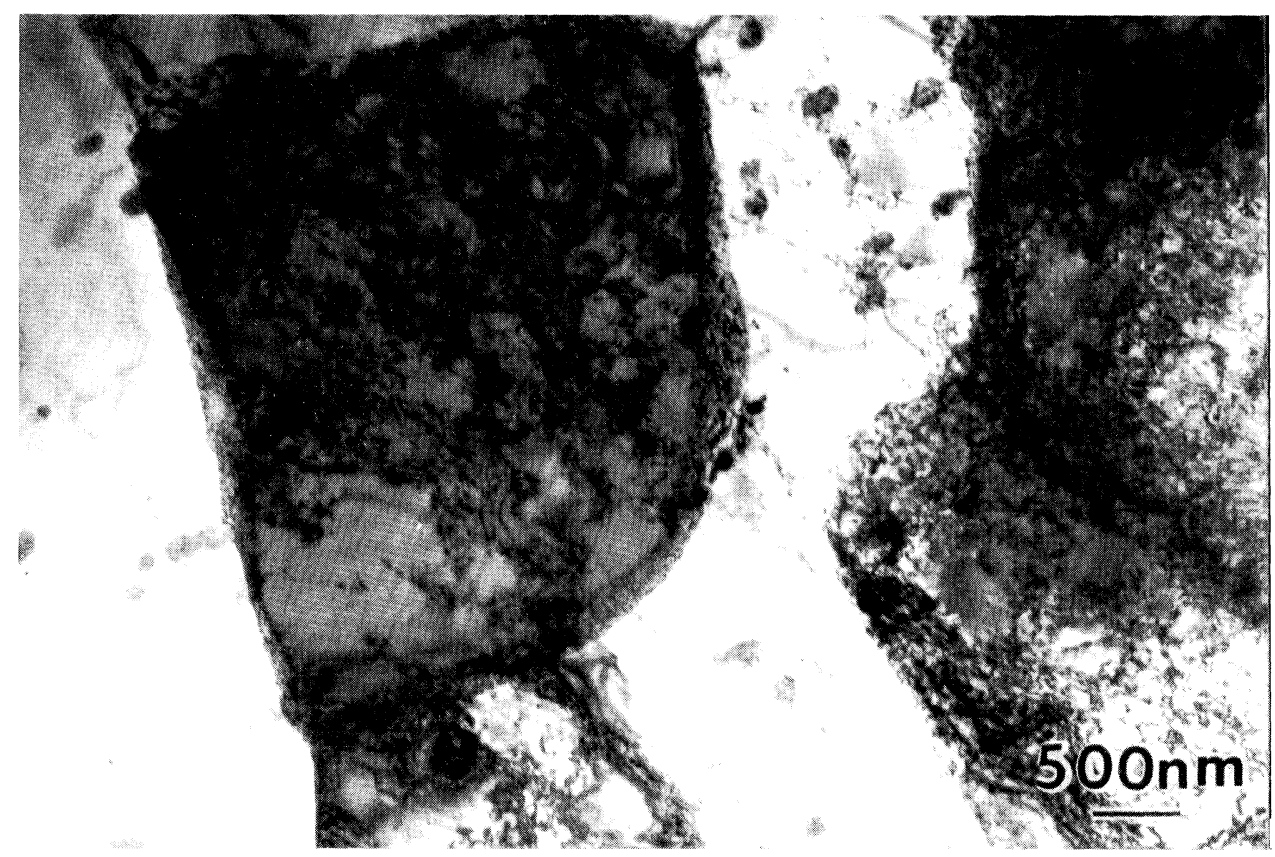

Figure 3 Subgrain structure after solution treatment for 3 hours at $400^{\circ} \mathrm{C}$; section normal to TD.

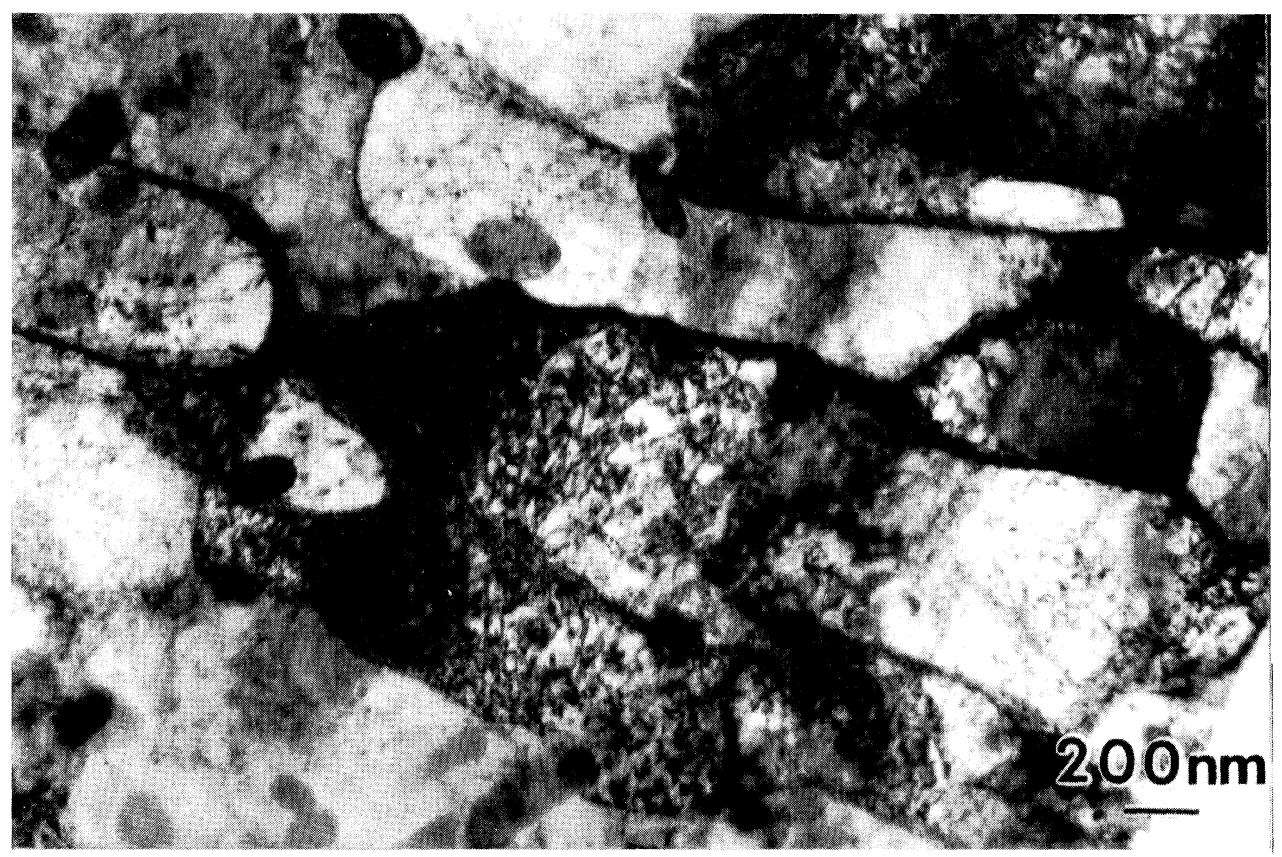

Figure 4 Elongated subgrains in material solution treated and rolled at $400^{\circ} \mathrm{C}$; section normal to TD. 


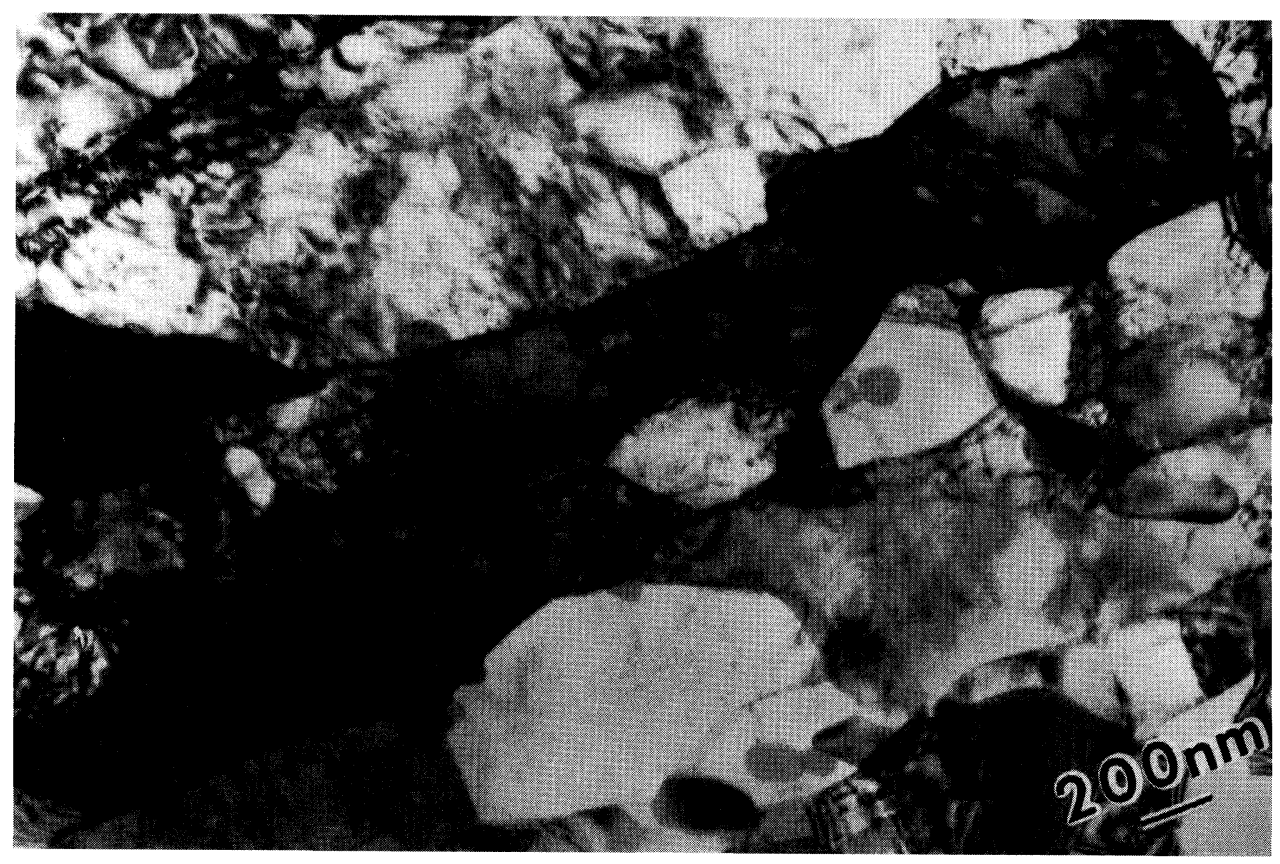

Figure 5 Banded structure in material solution treated at $400^{\circ} \mathrm{C}$, aged and rolled at $200^{\circ} \mathrm{C}$; section normal to TD.

After solution treatment at $580^{\circ} \mathrm{C}$ the structure was fully recrystallized but in the specimen rolled directly at that temperature this was replaced by a mixture of equiaxed and elongated subgrains in which the latter predominated (figure 6). The dislocation content was high in both types and the boundaries were sharp. The major change in specimens rolled at $200^{\circ} \mathrm{C}$ and $300^{\circ} \mathrm{C}$ was the development of microstructural inhomogeneities, superimposed on a matrix structure of elongated and equiaxed subgrains. These inhomogeneities were of two types:

(i) clusters of long banded features at $\pm 35^{\circ}$ to the rolling plane; these were many microns long and 200-400 nm thick and did not cross grain boundaries (figure 7), and

(ii) shear bands which were always at $\pm 35^{\circ}$ to the rolling plane and consisted of slightly elongated subgrains (figure 8).

Both features were superimposed on a matrix structure of nearly equiaxed subgrains. The dislocation content of all features was high and except for shear bands the misorientation between neighbouring structural units was relatively low. The local orientation in the shear bands was $\{110\}<311>$ when expressed in the rolling geometry, whereas that in the banded structure was close to $\{111\}<211>$. 


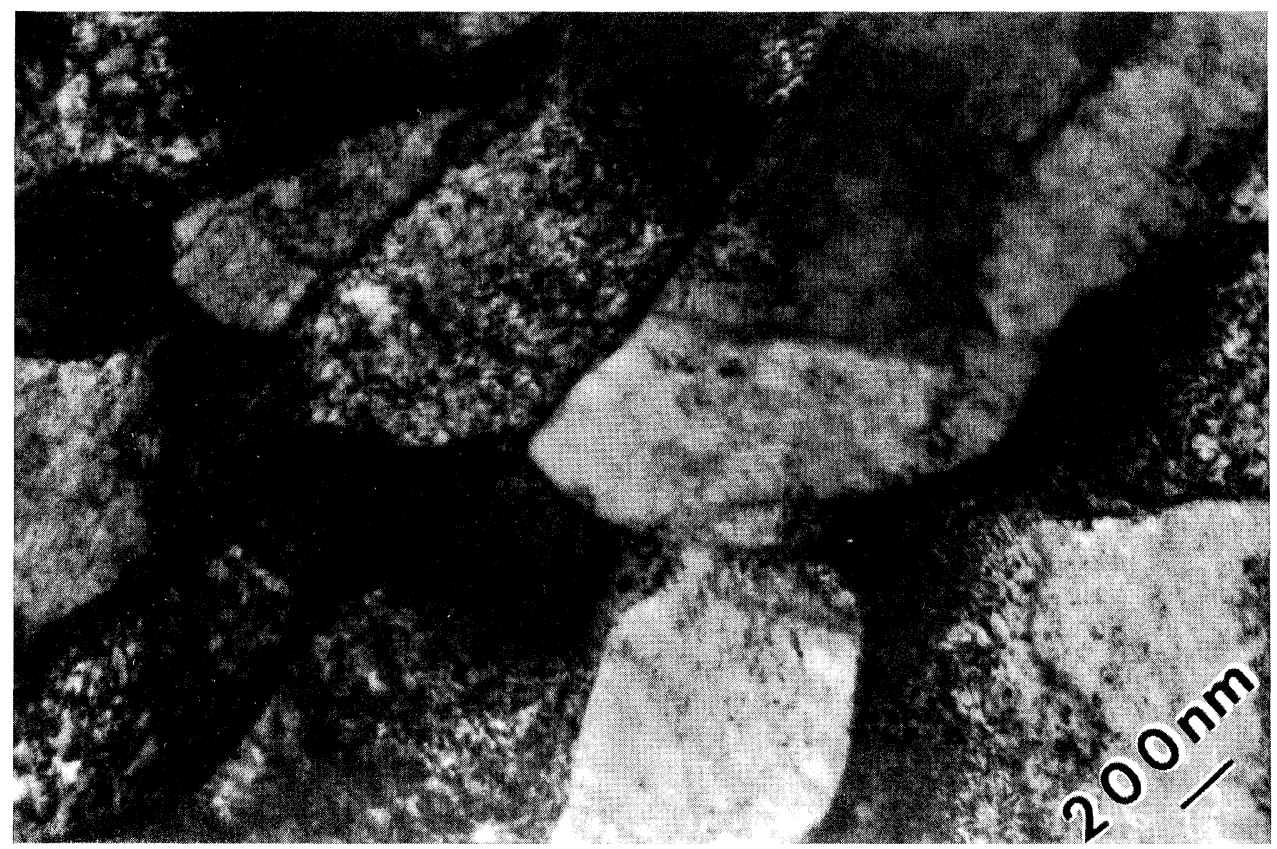

Figure 6 Elongated subgrains in material solution treated and rolled at $580^{\circ} \mathrm{C}$; section normal to TD.

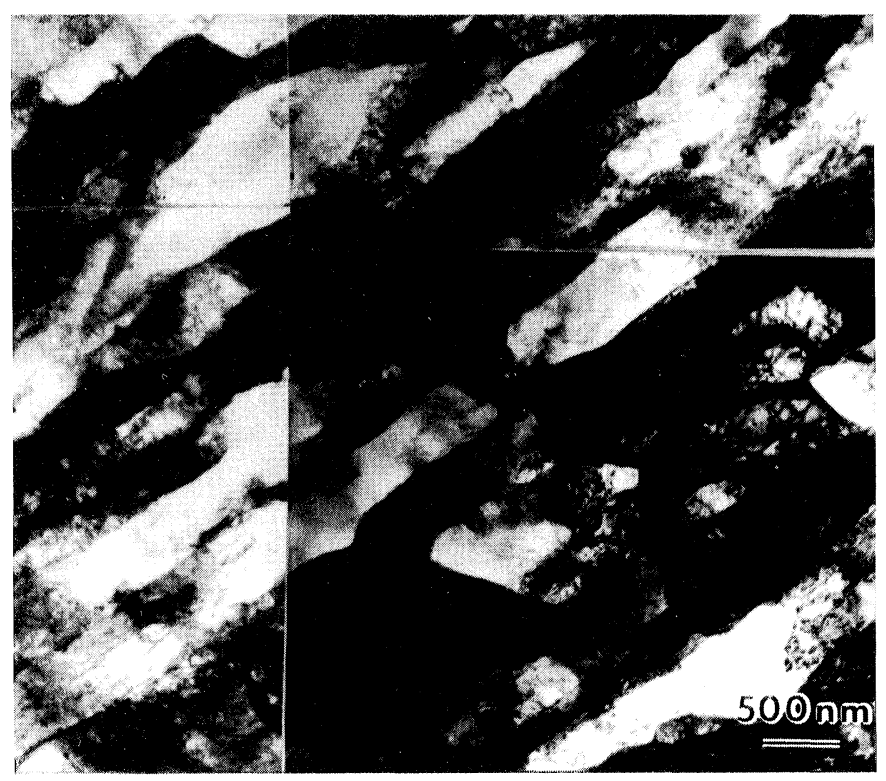

Figure 7 Banded elongated structure in material solution treated at $580^{\circ} \mathrm{C}$, aged and rolled at $200^{\circ} \mathrm{C}$, section normal to TD. 


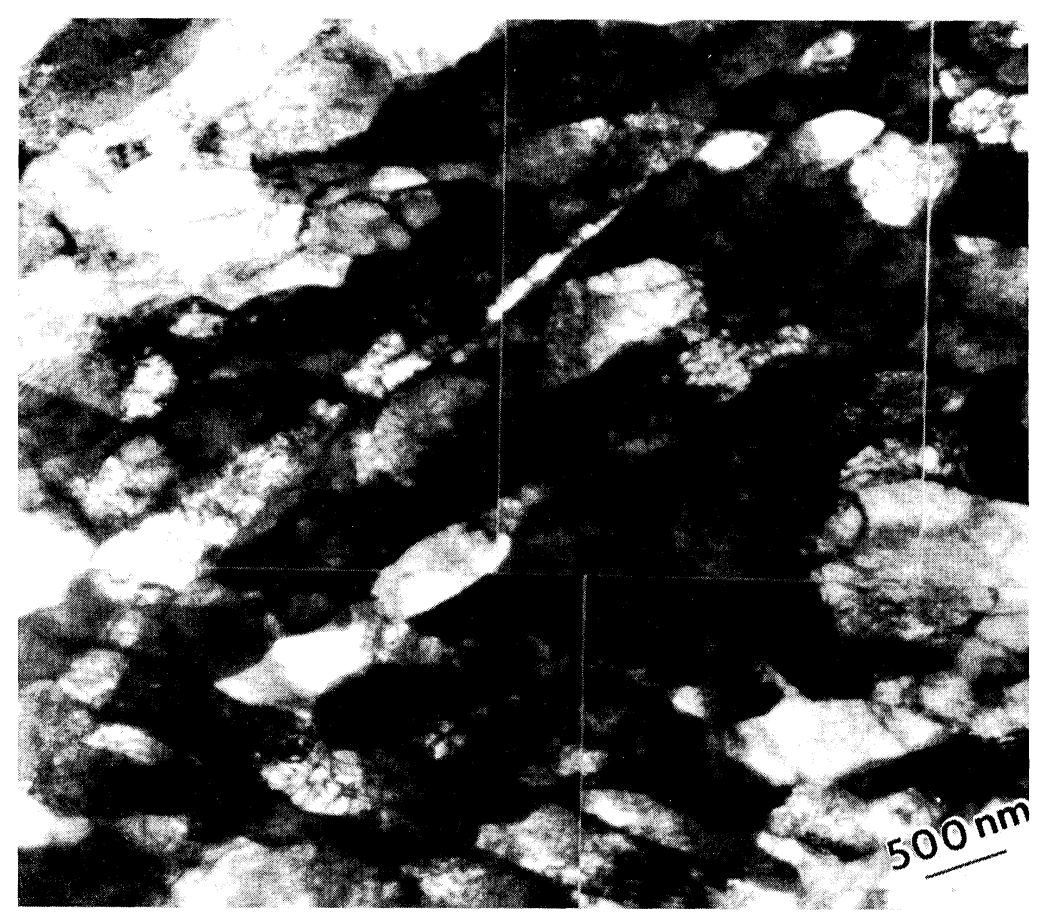

Figure 8 Shear bands in material solution treated at $580^{\circ} \mathrm{C}$, aged and rolled at $300^{\circ} \mathrm{C}$; section normal to TD.

\section{Texture}

The 111 pole figures for all rolled specimens were similar and typical of those normally found in rolled aluminium; figure 9 shows results for material rolled directly after solution treatment at $400^{\circ} \mathrm{C}$. ODF's for all 6 specimens are given in figures 10 and 11 and plots of the $\beta$ and $\alpha$ fibres for these are shown in figures 12 and 13 respectively.

Treatment at $400^{\circ} \mathrm{C}$. Material rolled directly after solution treatment at this temperature showed a well developed and rather flat $\beta$ fibre with minor concentration near $\mathrm{C}$ and to a lesser extent near B (figure 12). The $\alpha$ fibre was much less uniform and contained a prominent component near $\{011\}<311>$ with intensity $f(\mathrm{~g}) \sim 10$ and a less marked concentration on the opposite side of the B orientation, which was near $\{011\}<322>$ (figure 13). A minor cube component was also present in the ODF (figure 10a).

The ODF's for material rolled at $200^{\circ} \mathrm{C}$ and $300^{\circ} \mathrm{C}$ were dominated by a very strong $\mathrm{C}$ component with $\mathrm{f}(\mathrm{g})$ of $\sim 26$ and $\sim 32$ respectively (figures $10 \mathrm{~b}$ and $10 \mathrm{c}$ ). There was a steady decrease along the $\beta$ fibre to $S$ where the intensities were the same for each rolling temperature $(f(\mathrm{~g}) \sim 14)$ and thence to $\mathrm{B}(f(\mathrm{~g}) \sim 4)$ (figure 12). The $\alpha$ fibre was not strongly developed in these specimens and showed only minor concentrations near $\mathrm{B}$ for rolling at $300^{\circ} \mathrm{C}$, and on either side of this for rolling at $200^{\circ} \mathrm{C}$ (figure 13). The cube component was not present in either case and the rotated cube component, $\{001\}<110>$, found in unaged material was not detected. 


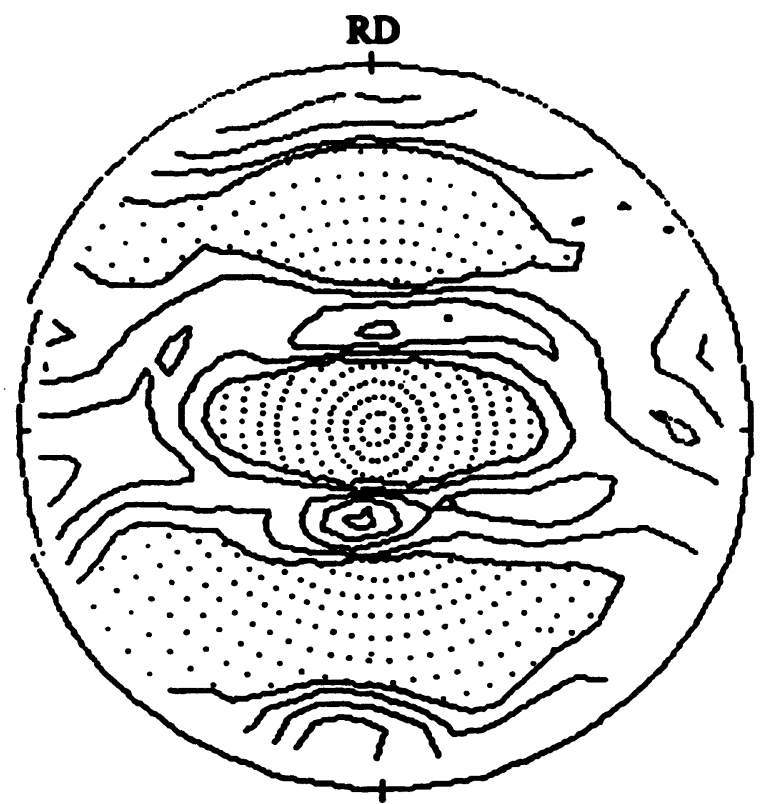

LEVELS :

MAX: 7.8

\section{5 - 1- 2-4-7}

Figure 9111 pole figure of material solution treated and rolled at $400^{\circ} \mathrm{C}$.

(a)

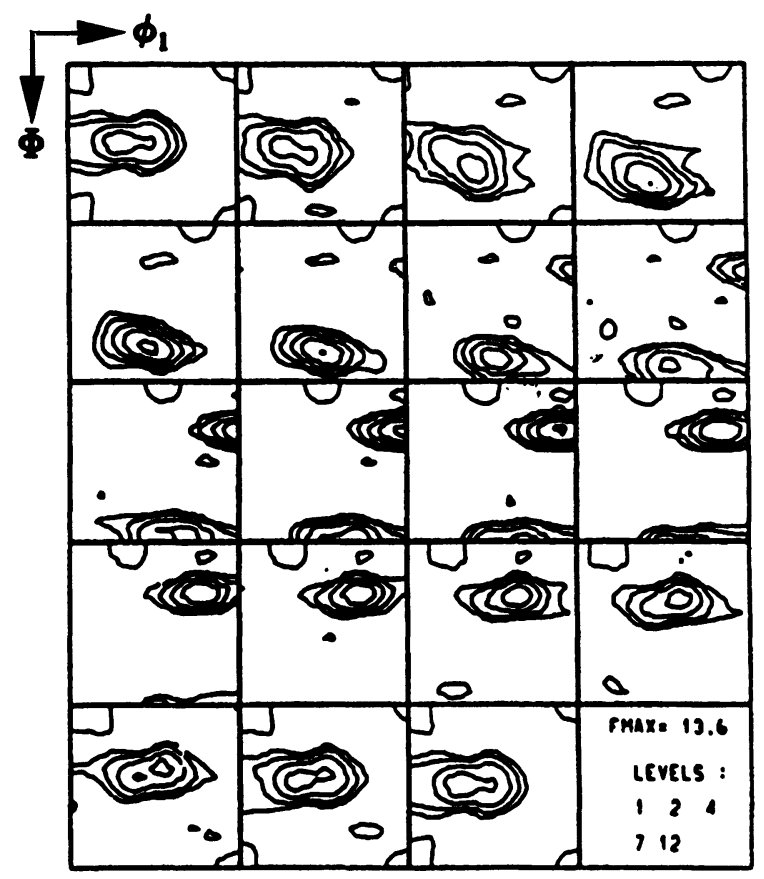


(b)

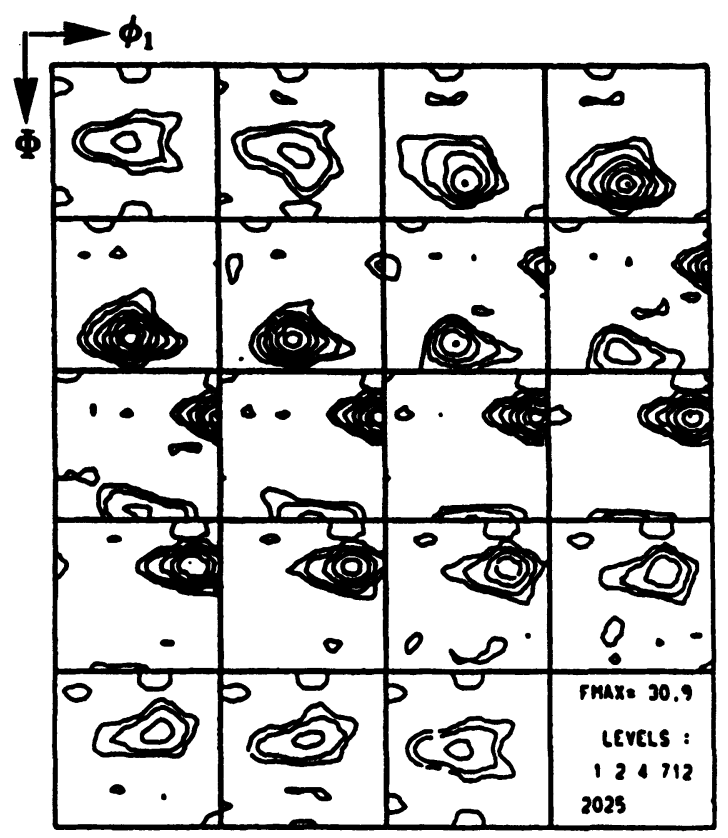

(c)

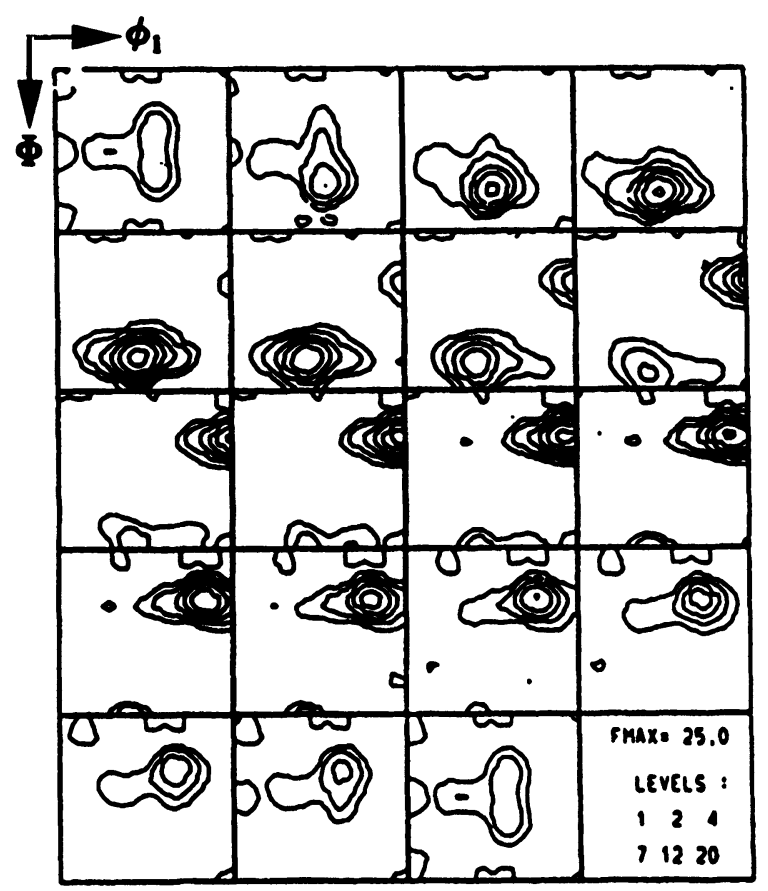

Figure 10 ODF's of metarial rolled after solution treatment at $400^{\circ} \mathrm{C}$ : (a) rolled at $400^{\circ} \mathrm{C}$; (b) aged and rolled at $300^{\circ} \mathrm{C} ;(\mathrm{c})$ aged and rolled at $200^{\circ} \mathrm{C}$. 
(a)

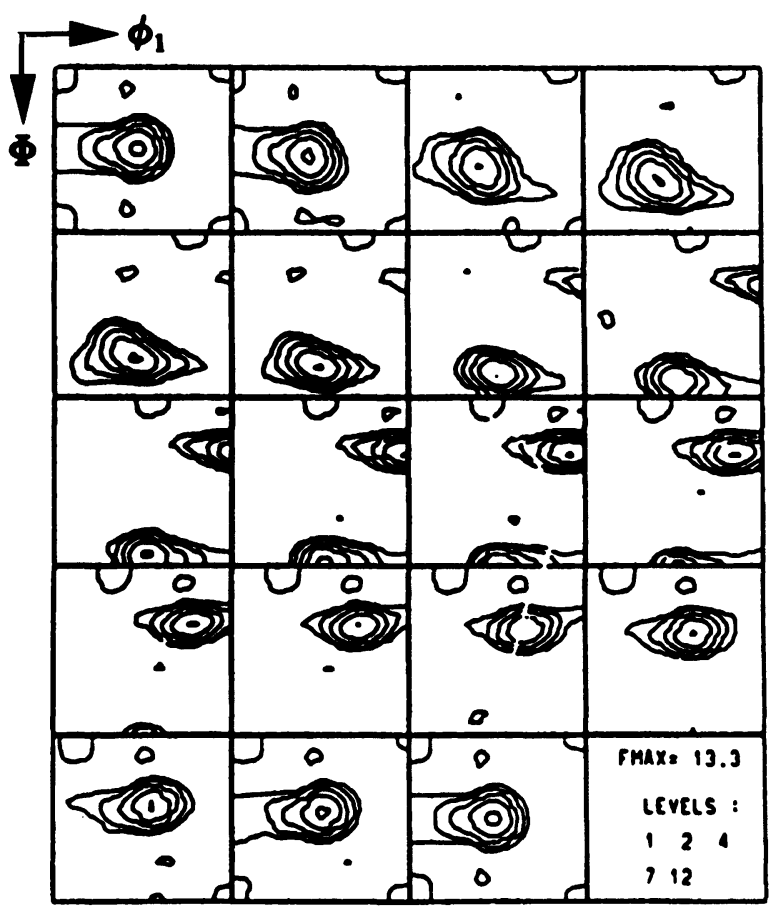

(b)

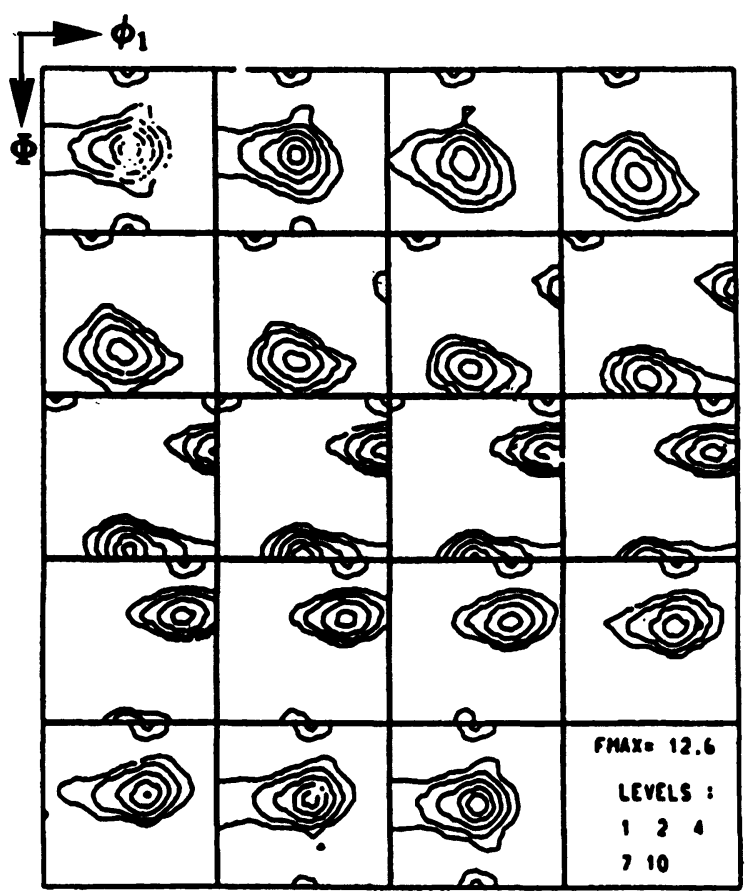


(c)

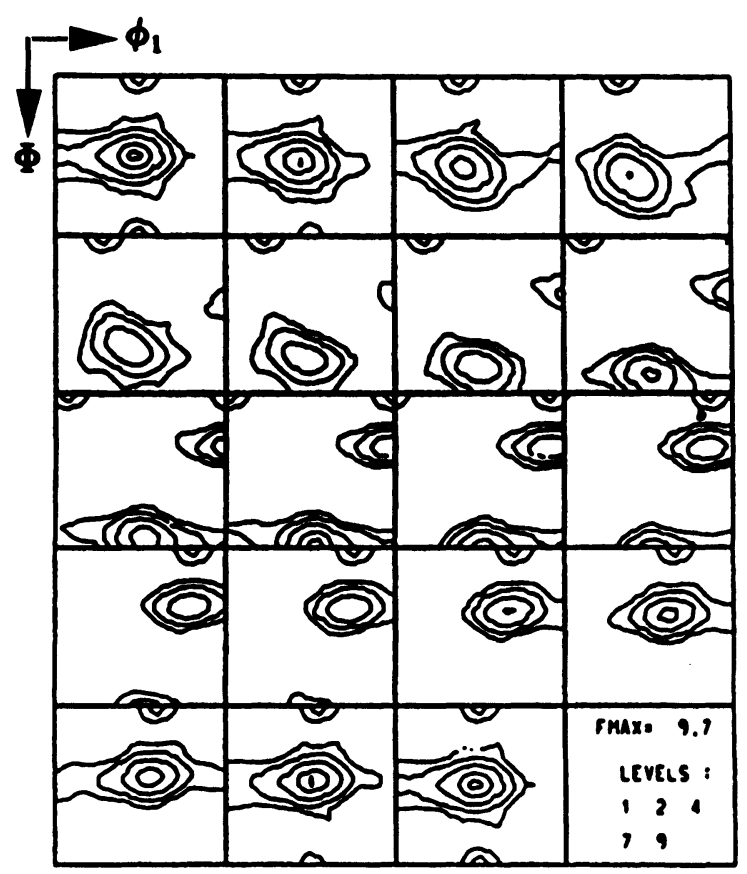

Figure 11 ODF's of metarial rolled after solution treatment at $580^{\circ} \mathrm{C}$ : (a) rolled at $580^{\circ} \mathrm{C}$; (b) aged and rolled at $300^{\circ} \mathrm{C}$; (c) aged and rolled at $200^{\circ} \mathrm{C}$.

Treatment at $580^{\circ} \mathrm{C}$. After solution treatment and rolling at this temperature the $\beta$ fibre was very uniform with $f(\mathrm{~g}) \sim 13$ (figure 12). The $\alpha$ fibre showed a well developed peak near $\{011\}<322>$ (figure 13). A minor cube component was also observed (figure 11a).

After ageing and rolling at $200^{\circ} \mathrm{C}$ and $300^{\circ} \mathrm{C}$ the cube component was no longer present but a small rotated cube component, $\{001\}<110>$, was found. The $\beta$ fibre in these specimens was again flat (figure 12), with no evidence of the strong $\mathrm{C}$ component present in specimens aged and rolled after solution treatment at $400^{\circ} \mathrm{C}$. The intensity in the fibre was weaker than in specimens aged and rolled after solution treatment at $400^{\circ} \mathrm{C}$. In both cases the $\beta$ fibre showed a small peak near B; the overall intensity along the fibre decreased as the rolling temperature was lowered. The $\alpha$ fibre intensities were stronger than those for specimens solution treated at $400^{\circ} \mathrm{C}$ and showed marked $\{011\}<322>$ concentrations that were similar to, but weaker than, that found in unaged material (figure 13). The $\alpha$ fibre became progressively weaker as the rolling temperature decreased.

Values of $f_{\max }$ for the various specimens are given in Table 2. It is noted that while the values for unaged material are apparently unaffected by the solution treatment and rolling temperatures used, those for material aged prior to rolling depend strongly on the former temperature. The values are much higher in the case of material solution treated at the lower temperature and there is a decrease with decreasing ageing temperature for both solution treatment temperatures. 


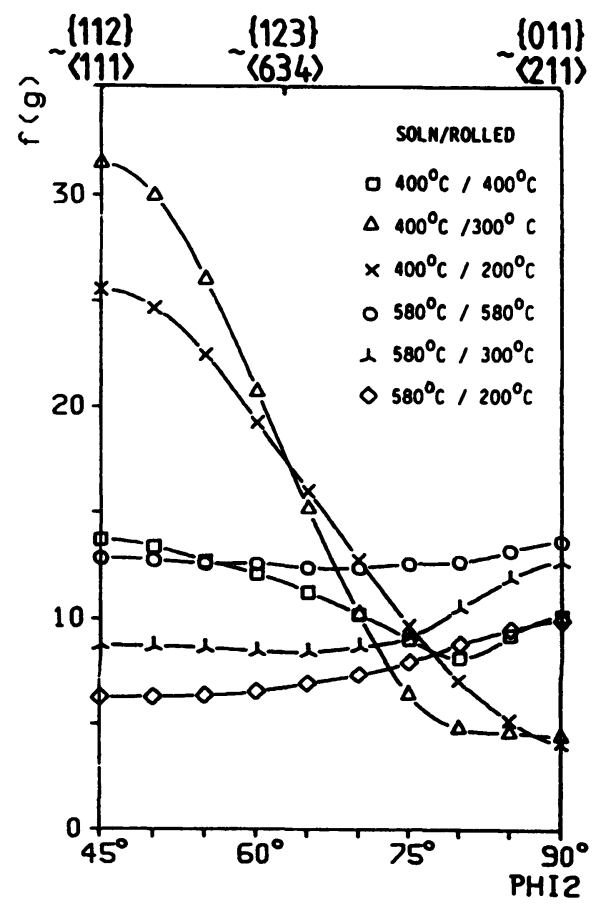

Figure 12 Density of orientations present in the $\beta$ fibre of rolled specimens.

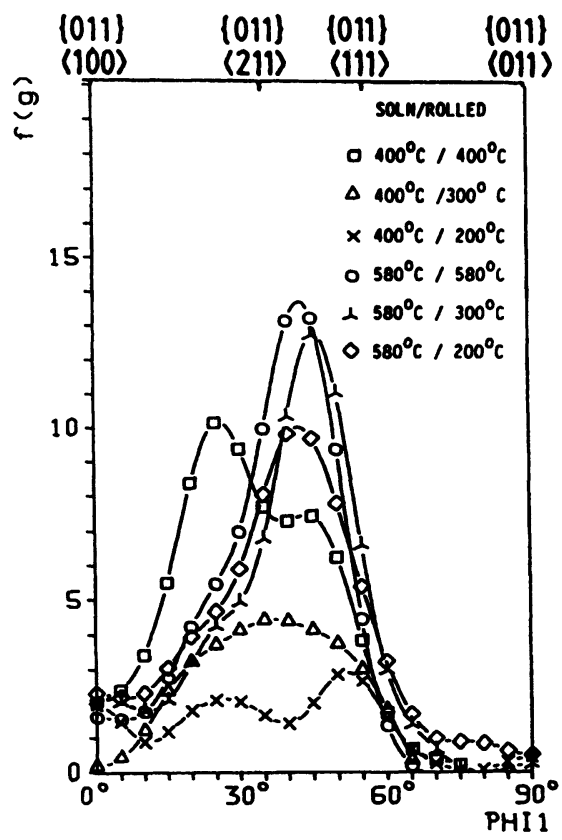

Figure 13 Density of orientations present in the $\alpha$ fibre of rolled specimens. 
Table 2 Values of $f_{\max }$ in Rolled Material

\begin{tabular}{lccc}
\hline Treatment & $f_{\max }$ & Treatment & $f_{\max }$ \\
\hline $400^{\circ} \mathrm{C}$, rolled & 13.6 & $580^{\circ} \mathrm{C}$, rolled & 13.3 \\
$400^{\circ} \mathrm{C}$, rolled $300^{\circ} \mathrm{C}$ & 30.9 & $580^{\circ} \mathrm{C}$, rolled $300^{\circ} \mathrm{C}$ & 12.6 \\
$400^{\circ} \mathrm{C}$, rolled $200^{\circ} \mathrm{C}$ & 25.0 & $580^{\circ} \mathrm{C}$, rolled $200^{\circ} \mathrm{C}$ & 9.7 \\
\hline
\end{tabular}

\section{DISCUSSION}

\section{Microstructure}

The microstructures of the rolled specimens fall into two categories. In one of these, illustrated by the specimens rolled without ageing at $400^{\circ} \mathrm{C}$ and $580^{\circ} \mathrm{C}$, the microstructure is free of band-type heterogeneities such as microbands, shear bands, etc. The structure consists of elongated subgrains with an aspect ratio of $\sim 2: 1$ and sharp boundaries; the dislocation content of the subgrains is relatively low in material rolled at $400^{\circ} \mathrm{C}$, but high after rolling at $580^{\circ} \mathrm{C}$. The absence of prominent heterogeneity is surprising. The initial materials from which these two sets of microstructures developed were quite different, in that the material rolled at $580^{\circ} \mathrm{C}$ was fully recrystallised with normal high angle grain boundaries, while that rolled at $400^{\circ} \mathrm{C}$ showed only recovered subgrains. The size and dispersion of the secondary precipitates were also different in each case, and so too, was the solute content of the matrix phase. The material rolled at $580^{\circ} \mathrm{C}$ had larger, more widely spaced particles and a higher solute concentration.

The second type of microstructure is seen in the specimens aged and rolled at $200^{\circ} \mathrm{C}$ and $300^{\circ} \mathrm{C}$. For both solution treatment temperatures, the structure is based on predominantly elongated subgrains, with long, similarly oriented, clustered narrow bands inclined at $\pm 25-35^{\circ}$ to the rolling plane. These features did not cross the grain boundaries of material treated at $580^{\circ} \mathrm{C}$ and were more frequent after rolling at $200^{\circ} \mathrm{C}$. The absence of cumulative misorientation across these clusters indicates that they are not transition bands. Normal shear bands were present for both ageing/rolling temperatures in material solution treated at $580^{\circ} \mathrm{C}$ and these were more frequent after deformation at $200^{\circ} \mathrm{C}$.

In recent years the microstructure of cold rolled aluminium has been examined in detail and much attention has been paid to the development of microstructural inhomogeneity. It is clearly established that at the level of strain used here $(\varepsilon \sim 1.6)$ the microstructure consists of several different inhomogeneities of deformation in a matrix structure of more equiaxed "cell blocks" (Hansen, 1990; Bay et al, 1992; Rosen et al, 1995). The major relevant inhomogeneities are microbands of two types (MBI and MBII) and shear bands. Microbands of type MBI are non crystallographic in nature and appear as long banded features which are often clustered, usually confined to single grains, and have orientations similar to that of the matrix cell blocks. The long banded features seen in the present work after rolling at $200^{\circ} \mathrm{C}$ and $300^{\circ} \mathrm{C}$ are characteristic of this type of inhomogeneity. It is relevant that these features were not seen in material rolled at either $400^{\circ} \mathrm{C}$ or $580^{\circ} \mathrm{C}$. Microbands of type MBII are crystallographic in nature and are observed in many medium - high SFE materials; this type of inhomogeneity was not observed in the present warm rolled specimens. 
Somewhat different structures have been reported in alloys containing larger amounts of magnesium. In these alloys, the cross slip and climb of dislocations that lead to dynamic recovery are retarded by the solute atoms and cell type structures do not form. Korbel et al. (1986) observed crystallographic microbands (MBII's in Hansen's notation) in a cold rolled $4.8 \% \mathrm{Mg}$ alloy, that formed on $\{111\}$ planes at relatively low strains and developed subsequently, into clusters. At large strains the clusters were seen to cross grain boundaries and so develop into shear bands. Similar results have been reported by Liu et al. (1986) in a cold rolled 3004 alloy while Bird et al. (1986) have described the microstructure of a cold rolled $4.40 \% \mathrm{Mg}, 0.4 \% \mathrm{Mn}$ alloy in terms of "crystal scale" (< grain size) and "sample scale" (sheet thickness) shear bands. A more detailed study by Hughes (1993) reported that the dislocations defined a so-called Taylor lattice, from the boundaries of which the crystallographic microbands developed. The nature of the various banded structures found in rolled aluminium and its alloys, and the nomenclature used to describe them need clarification. At one extreme, are the bands found by Korbel et al. (1986) in cold rolled $4.8 \% \mathrm{Mg}$, that are associated with minimum amounts of dynamic recovery and develop at relatively low strains into shear bands. At the other extreme, are the first generation, non-crystallographic microbands observed by Bay et al. (1992) at quite low strains in pure aluminium; in this case dynamic recovery is favoured. Rosen et al. (1995) have recently reported localized shear zones (S-bands) in this material after $50 \%$ reduction that are parallel to $\{111\}$ planes. It seems likely that there may be a spectrum of banded structures generated during deformation that is governed by many factors including temperature, strain, strain rate, stacking fault energy, together with recovery processes of various types, etc.

There have been fewer examinations of microstructure in warm, or hot rolled aluminium. It is to be expected that in this high SFE metal the major factor affecting the structure would be the extent of dynamic recovery. This is also governed by such factors as total strain, strain rate and temperature of deformation. The significance of dynamic recovery has been pointed out by Hansen and Juul Jensen (1991) who observed that, for deformation at temperatures $>0.5 \mathrm{~T}_{\mathrm{m}}\left(\sim 190^{\circ} \mathrm{C}\right)$, the structure of rolled aluminium consists of almost equiaxed subgrains together with transition bands. However, as pointed out above, there is considerable confusion about the nature and extent of banding in the microstructure and this probably has its origin in strain rate and temperature effects i.e. in the Zener-Holloman parameter, $\mathrm{Z}$.

Humphreys and Kalu (1990) found no transition bands in pure aluminium deformed in compression at $200^{\circ} \mathrm{C}$ with a slow strain rate $\left(\dot{\varepsilon}<10^{-3} \mathrm{~s}^{-1}\right)$, whereas Sheppard et al. (1986) reported transition bands in commercial purity aluminium rolled at 345$460^{\circ} \mathrm{C}$ with $\dot{\varepsilon}=2-3.5 \mathrm{~s}^{-1}$. Ren and Morris (1995) also examined commercial purity aluminium after rolling in a single pass, at $510^{\circ} \mathrm{C}$ with $\dot{\varepsilon}=14.4 \mathrm{~s}^{-1}$. After $60 \%$ reduction the structure consisted of elongated grains that contained banded features, identified as shear bands. At higher reduction dynamic recrystallization became increasingly evident but even after $90 \%$ reduction the few remnant elongated grains still contained shear bands. Banding has also been observed by Baxter et al. (1995) in a current extensive examination of $\mathrm{Al}-1 \% \mathrm{Mg}$ after plane strain compression at $385^{\circ} \mathrm{C}$ and $455^{\circ} \mathrm{C}$ and strain rates, $\varepsilon=2.5 \mathrm{~s}^{-1}$ and $25 \mathrm{~s}^{-1}$. The bands, which were $2-8 \mu \mathrm{m}$ wide, formed in a structure of elongated grains and at $\pm 35^{\circ}$ to the "rolling plane". They were composed of subgrains $(\sim 1-3 \mu \mathrm{m})$ that were slightly elongated in the direction of the bands. The larger subgrains were associated with lower values of $\mathrm{Z}$.

If these results are compared with those for the present warm rolled material it seems clear that at some temperature between $300^{\circ} \mathrm{C}$ and $400^{\circ} \mathrm{C}$ the nature of microstructural 
development changes and that homogeneity becomes the norm. Deformation above this temperature results in homogeneous microstructures that are, apparently, independent of major changes in the deformation temperature, solute concentration and particle size and distribution. It is believed that this change is largely the result of a temperature dependant increase in the rate of dynamic recovery, which ensures that despite the presence of $\sim 1 \% \mathrm{Mg}$ in solid solution work hardening never becomes great enough to produce an orientation change sufficiently large to induce heterogeneity. It is possible, however, that other factors, such as the crystallography of deformation may be involved. There has been increasing recent discussion of the role of non-octahedral slip in the generation of deformation textures (Bacroix and Jonas, 1988) and Maurice and Driver (1993) have examined (001)[110] single crystals of an A1-1\% Mn alloy that were homogenized and aged before plane strain compression to $\varepsilon=1.5$, at $200-400^{\circ} \mathrm{C}$ and with $\dot{\varepsilon}=10^{-3} \mathrm{~s}^{-1}$ and $10^{-1} \mathrm{~s}^{-1}$. No inhomogeneities of deformation were observed in crystals compressed at $400^{\circ} \mathrm{C}$, but deformation bands and transition bands were common after deformation at $200^{\circ} \mathrm{C}$. Between $200^{\circ} \mathrm{C}$ and $300^{\circ} \mathrm{C}$ the microstructure was determined by the strain rate, with low values $\left(\dot{\varepsilon}=10^{-3} \mathrm{~s}^{-1}\right)$ producing homogeneous structures. The operating slip system at high temperatures was $\{110\}<110>$; at lower temperatures normal octahedral slip occurred. A (001)[110] crystal deformed by octahedral slip over the full range of temperature used. The slip behaviour of other orientations at high temperatures is unknown, but the stability of the cube orientation in single crystals and polycrystals during hot deformation is well established and is discussed below.

\section{Texture}

Inspection of the ODF's reveals some significant effects; this is particularly so if the nature of the various $\beta$ fibres is considered (figure 12).

(i) There is a marked effect of solution treatment temperature on the results obtained after ageing and rolling at $200^{\circ} \mathrm{C}$ and $300^{\circ} \mathrm{C}$. After solution treatment for 3 hours at $400^{\circ} \mathrm{C}$, the intensity distribution in the $\beta$ fibre of these specimens was very uneven with a strongly developed $C$ component, and a steady decrease through $S$ to a very low value near $B$. In the specimens rolled after solution treatment for 48 hours at $580^{\circ} \mathrm{C}$ the intensity distribution in the $\beta$ fibre was uniform and the intensities were low.

The two sets of specimens differed mainly in the solute concentration and the size and spacing of the second phase particles. The first of these should result in a lowered value of SFE after treatment at $400^{\circ} \mathrm{C}$ (i.e. a decreased possibility of dynamic recovery) while the second should promote the development of a cold worked texture. Es-Said and Morris (1986) have reported that the addition of fine particles to a carefully homogenised 3004 alloy strengthened the C component after cold rolling.

(ii) Only minor differences were observed between specimens rolled at the two solution treatment temperatures $\left(400^{\circ} \mathrm{C}\right.$ and $\left.580^{\circ} \mathrm{C}\right)$. The results compliment those observed in the microstructural examination of these specimens which were virtually free of heterogeneity despite differences in particle dispersion and solute concentration. It is clear that any possible particle based effects have been negated by the higher rolling temperatures. The minor cube component found in both cases is to be expected. It is well established that any initial cube oriented material is lost only slowly during hot rolling. 
There have been several recent discussions of texture development in hot rolled aluminium alloys but there is no general agreement between these and the present work. Hirsch (1991) rolled wedge shaped specimens of two different alloys in a single pass to varying reductions. In a 5042 alloy $\left(\mathrm{Mg}>3 \%\right.$ ), rolled to $73 \%$ reduction at $370^{\circ} \mathrm{C}$ and $480^{\circ} \mathrm{C}$ the $\beta$ fibre was fairly uniform with low intensities of the $\mathrm{C}$ and $\mathrm{S}$ orientations and a small concentration near $\mathrm{B}$. The results were similar for both rolling temperatures although the $\mathrm{C}$ component was a little stronger at $480^{\circ} \mathrm{C}$. With further rolling the $\mathrm{B}$ orientation emerged as the main texture component and its strength increased with strain and rolling temperature. The present work is in reasonable agreement with these results and higher B concentrations are a common feature for higher temperature rolling. In a 7050 alloy, where the presence of $\mathrm{Zr}$ would be expected to stabilize the deformed structure, the $\beta$ fibre showed a low density of $C$ orientations and a concentration of $B$ for all temperatures between $260^{\circ} \mathrm{C}$ and $440^{\circ} \mathrm{C}$. Hirsch argued that the $\mathrm{B}$ orientation emerged as the typical high temperature rolling texture component, because many grains deformed in an unconstrained manner, and went on to show that a Sachs type (no constraints) model predicted the development of $B$ orientations. It is relevant that widening is a feature of warm/hot rolling and that $\sim 10 \%$ widening was observed in the present case.

Panchanadeeswaran and Field (1995) deformed commercial purity aluminium in plane strain compression at $375^{\circ} \mathrm{C}$ and at the much lower strain rate of $\dot{\varepsilon}=0.05 \mathrm{~s}^{-1}$. For a randomly oriented specimen the texture was sharper than that developed after deformation at room temperature. The intensity distribution along the $\alpha$ and $\beta$ fibres was uniform at values of strain $<\varepsilon=1$, but at higher strains there was a sharp rise in intensity between $S$ and $C$. For a specimen that had an initial strong cube component, hot deformation led to a prominent $\mathrm{B}$ component and only weak intensity near $\mathrm{C}$.

In their examination of a similar commercial purity aluminium rolled at $510^{\circ} \mathrm{C}$ in a single pass Ren and Morris (1995) found that for $75 \%$ reduction the $\beta$ fibre showed a strong component near $\mathrm{C}$. The $\beta$ fibre was very similar to that shown in figure 12 for material solution treated at $400^{\circ} \mathrm{C}$ and rolled at either $200^{\circ} \mathrm{C}$ or $300^{\circ} \mathrm{C}$. The peak near $C$ was reported to be at $\{4,4,11\}<11,11,8>$, i.e., at an expected cold rolling component. At higher strain levels dynamic recrystallization occurred and the $\beta$ fibre was both weak and flat.

\section{CONCLUSIONS}

1. Rolling of 3004 to $75 \%$ reduction in a single pass, at temperatures $>400^{\circ} \mathrm{C}$, leads to microstructures that are apparently free of banded heterogeneities. The textures of such materials are relatively flat and weak.

2. In material rolled at lower temperatures an effect of prior solution temperature is evident in both microstructure and texture. If the solution temperature is high, i.e., if the solute concentration and particle dispersion are high, the microstructures are free of shear bands and the textures are flat and weak. If the solution treatment temperature is lower, i.e., if the solute concentration and the interparticle distance are low, microstructural heterogeneity in the form of banded structures (including shear bands) occurs and the textures are much stronger.

3. These results are associated with changes in the extent of dynamic recovery. 


\section{Acknowledgments}

This paper is based on part of a Ph.D. project carried out in the School of Materials Science and Engineering, University of New South Wales (Schumann, 1989). Financial and technical support was provided by Comalco Research Centre; Dr. J. Hirsch gave generous help with the gathering of texture data during a visit by G.O.S. to Institut für Allgemeine Metallphysik und Metallkunde (Aachen).

\section{References}

Baxter, G. J. et al. (1995). 16th Riso International Symposium on Materials Science (in press).

Bacroix, B. and Jonas, J. J. (1988). Text. Microst., 8 \& 9, 267.

Bay, B., Hansen, N., Hughes, D. A. and Kuhlmann-Wilsdorf, D. (1992). Acta metall. mater., 40, 205.

Bird, J. E., Newman, K. E., Narasimhan, K. (1986). Aluminium Technology '86, Ed. Sheppard T., The Institute of Metals, 604.

Hansen, N. and Juul Jensen, J. (1991). Hot Deformation of Aluminium Alloys, Eds. Langdon et al, The Minerals, Metals and Materials Society, 3.

Hirsch, J. R. (1991). ibid, 379.

Humphreys, F. J. and Kalu P. N. (1990). Acta metall. mater., 38, 917.

Hutchinson, W. B., Oscarsson, A. and Karlsson, A. (1989). Mat. Sci. and Tech., 5, 1118.

Korbel, A., Embury, J. D., Hatherly, M., Martin, P. L. and Erbsloh, H. W. (1986). Acta metall., 34, 1999.

Liu, Y-L., Delaey, L. and Baekeland, J. P. (1986). Aluminium Technology '86, Ed. Sheppard T., The Institute of Metals.

Maurice, C. L. and Driver, J. H. (1993). Acta metall. mater., 41, 1653.

Panchanadeeswaran, S. and Field, D. P. (1995). ibid, 43, 1683.

Ren, B. and Morris, J. G. (1995). Metall. and Mater. Trans., 26A, 31.

Rosen, G. I., Juul Jensen, D., Hughes, D. A. and Hansen, N. (1995) Acta metall. mater., 43, 2563.

Schumann, G. O. (1989). Ph.D. thesis, University of New South Wales, Sydney. 